\title{
CONSTITUTIONAL LAW: "DELIBERATE SPEED" \\ DOCTRINE APPLIED TO DESEGREGATION OF RECREATIONAL FACILITIES
}

THE "deliberate speed" doctrine of Brown v. Board of Education,"
which contemplates allowing a delay in the desegregation of public
elementary and secondary schools when certain conditions exist,
was unequivocally applied to cases involving the desegregation of
public recreational facilities by the Court of Appeals for the Sixth
Circuit in the recent case of Watson $v$. City of Memphis.
Plaintiffs brought a class action against the Memphis Park Com.
mission and others for an injunction immediately restraining the
city from operating and maintaining certain public parks and recrea.
tional facilities on a racially segregated basis. The district court
rendered a judgment denying the injunction but approving a plan
proposed by defendants for the gradual desegregation of certain of
the facilities and ordering the Commission to file, within six months,
a further plan for the desegregation of all recreational facilities of
the city. Plaintiffs appealed on the ground that the law permits no
delay in the desegregation of public parks and recreational facilities.
Defendants at no time questioned the right of plaintiffs to participate
in the use of the recreational facilities on a desegregated basis, ${ }^{3}$ but
rather they contended that the public interest of both the white and

1349 U.S. 294 (1955).

"[T] such orders and decrees consistent with this opinion as are necessary and proper to admit to public schools on a racially nondiscriminatory basis with all deliberate speed the parties to these cases." Id. at 301. (Emplrasis added.)

For discussion of such implementation of desegregation, see McKay, "With $A l l$ Deliberate Speed"-A Study of School Desegregation, 31 N.Y.U.L. REv. 991 (1956); McKay, "With All Deliberate Speed": Legislative Reaction and Judicial Development, 1956-1957, 43 VA. L. REv. 1205 (1957); Papale, Judicial Enforcement of Desegregation: Its Problems and Limitations, 52 Nw. U.L. REv. 301 (1957); Comment, 65 YALE L.J. 630 (1956); Note, 71 HaRv. L. REv. 486 (1958); Note, 49 Nw. U.L. REv. 557 (1954); Note, 64 YAIE L.J. 124 (1954).

a 303 F.2d 863 (6th Cir. 1962), cert. granted, 31 U.S.L. WEEK 3169 (U.S. Nov. 19, 1962) (No. 424).

"We are of the view that the principle stated in Brown v. Board of Education, supra, relating to the desegregation of schools, is applicable to the present case, involving the desegregation of recreational facilities in the City of Memphis. In our opinion the Brown decision is not limited to cases involving public schools . ..." 303 F.2d at 869 .

${ }^{3}$ See Brief for Defendants-Appellees, pp. 10-11, 17. The respondents, in opposition to their opponents' petition for certiorari, said: "Respondents fully recognize . . . the established principle of constitutional law that Negroes are entitled to make use, on a desegregated basis, of public parks and recreational facilities of the City of Memphis." Brief of Respondents, p. 1 . 
Negro inhabitants of Memphis demanded that desegregation be implemented gradually. The court of appeals, agreeing with the Commission, held that the implementation of desegregation "with all deliberate speed" was warranted in this case.

The fundamental question raised once again by this case is: To what extent, if at all, may the vindication of already adjudicated and determined constitutional rights be delayed in furtherance of the public interest.

Relying on general equitable principles, the Supreme Court has long recognized and exercised its power to delay remedies where it appeared that immediate enforcement of claimant's right might bring about unjustifiable injury. ${ }^{4}$ The creation of public health hazards, ${ }^{5}$ the imposition of other public hardships, ${ }^{6}$ and the subjection of the defendant to an excessive loss without commensurate benefit to the plaintiff, ${ }^{7}$ have been held to be such injuries as would justify gradual implementation. Similarly, in government antitrust suits, the magnitude and complexity of the interests involved often require that gradual remedies be employed. ${ }^{8}$ A related reason calling for gradualism in these cases is the possible serious injury that might result if certain products upon which the public depended were immediately removed from interstate commerce. ${ }^{9}$

For discussion of the Supreme Court's exercise of equity discretion, see Note, Supreme Court Equity Discretion: The Decrees in the Segregation Cases, 64 Yale. L.J. 124 (1954).

SIn Wisconsin v. Illinois, 278 U.S. 367 (1929), modified, 281 U.S. 179 (1930), 289 U.S. 395 (1933), 309 U.S. 569, 311 U.S. 107 (1940), the Court, while ruling that the plaintiff states were entitled to an injunction to prohibit the Sanitary District of Chicago from diverting water from Lake Michigan, nevertheless ordered a gradual decree which would allow the Sanitary District a reasonably practicable time within which to find another means of disposing of sewage. The granting of an immediate injunction would have involved the risk of a grave health hazard to the public.

- Organized Village v. Egan, 369 U.S. 60, 76 (1962). In this case the Court held that the citizens of two Alaskan Eskimo fishing villages must cease violating a statute prohibiting the use of fish-traps, but, "in order to avoid hardship," allowed a "stay" to the end of the 1962 salmon fishing season.

II Arizona Copper Co. v. Gillespie, 230 U.S. 46 (1913), the defendants were allowed a reasonable time to alleviate water pollution caused by their mining, because ordering immediate cessation would have destroyed their industry. See Georgia v. Tennessee Copper Co., 206 U.S. 230 (1907), modified, 237 U.S. 474 (1915), 240 U.S. 650 (1916) (smoke nuisance); Westinghouse Air Brake Co. v. Great Northern Ry., 86 Fed. 132 (C.C.S.D.N.Y. 1898) (patent infringement).

${ }^{8}$ Sce, e.g., United States v. E. I. duPont de Nemours \& Co., 366 U.S. 316 (1961); Schine Chain Theaters, Inc. v. United States, 334 U.S. 110 (1948); United States v. American Tobacco Co., 221 U.S. 106 (1911); Standard Oil Co. v. United States, 221 U.S. 1 (1911).

- In Standard Oil Co. v. United States, supra note 8, at 8I, the Court hoped, by 
None of these cases, however, involved a meritorious claim seeking the protection of personal rights; it is quite another situation for a court to adjudge that a person has a positive, personal right which is being unconstitutionally denied him, but that he must, nevertheless, await the enjoyment of that right. It was not until the rendering of the decision in the second Brown case ${ }^{10}$ that the Supreme -Court was willing to go this far. ${ }^{11}$

The Brown v. Board of Education conclusion that "separate educational facilities are inherently unequal"12 necessarily affected a large number of people in the nation's complex public school system. $^{13}$ Therefore, in the second Brown decision, the Court ordered that desegregation of public schools was to be effected, not

allowing reasonable time, to avoid "possible serious injury to result to the public from an absolute cessation of interstate commerce in petroleum and its products by such vast agencies as are embraced in the combination...."

An immediate application of the remedy was not made in United States v. American Tobacco Co., supra note 8 , at 187 , because, among other things, an injunction prohibiting the movement in interstate commerce of the products produced by the combination would lead to "a stoppage of supply and a great enhancement of prices."

10949 U.S. 294 (1955).

11 See 64 YALE L.J. 124, 126-27 (1954).

The Court had approached most closely the deciding of this question in Youngstown Sheet \& Tube Co. v. Sawyer, 343 U.S. 579 (1952). The President, in order to avert a steel strike which threatened to paralyze the Korean War effort, ordered seizure of the steel industry. The government contended that, even if the seizure were unconstitu. - tional, the public interest prevented the issuance of an injunction against the scizurc. Instead of ordering that an injunction issue after the government had had time to avcrt the emergency, the Court granted immediate rehef. Only Mr. Justice Frankfurter's concurring opinion answered the government's contention: "'Balancing the equities' when considering whether an injunction should issue, is lawyers' jargon for choosing between conflicting public interests. When Congress itself has struck the balance,... a court of equity is not justified in ignoring that pronouncement under the guise of exercising cquitable discretion." Id. at 609-10.

Some state and lower federal court school decisions under Plessy v. Ferguson, 163 U.S. 537 (1896), however, did render gradual decrees to allow time for accomplishing administrative tasks necessary to equalize educational facilities. See, e.g., Davis v. County School Bd., 103 F. Supp. 337 (E.D. Va. 1952), rev'd on other grounds sub nom. Brown v. Board of Education, 349 U.S. 294 (1955); Briggs v. Elliott, 98 F. Supp. 529 (E.D.S.C. 1951), vacated, 342 U.S. 350, modified and affd, 103 F. Supp. 920 (E.D.S.C. 1952), rev'd on other grounds as modified sub nom. Brown v. Board of Education, supra; Wrighten v. Board of Trustees, 72 F. Supp. 948 (E.D.S.C. 1947).

12 "[I]n the field of public education the doctrine of 'separate but equal' has no : place. Separate educational facilities are inherently unequal." 347 U.S. 483, 495 (1954).

13 Forty per cent of the public school pupils in the United States were directly affected by the Brown decision. In the District of Columbia and the seventeen states which required segregation, 8,200,000 white children and 2,530,000 Negro children were attending the schools. N.Y. Times, May 18, 1954, p. 18, col. 1. 
immediately, but "with all deliberate speed."14 Furthermore, because of the peculiarly local nature of the problems, the Court determined that the district courts were the appropriate organs to implement gradual desegregation. It accordingly formulated the criteria by which the lower courts were to be guided in implementing such desegregation ${ }^{15}$ and remanded the cases to them.

The Supreme Court made it clear that only very practical matters incident to the services rendered by the public schools were to be evaluated in determining whether the public interest called for delay in desegregation. The courts were expressly authorized to consider problems related to administration-specifically, those arising from the physical condition of the school plant, the school transportation system, personnel, the revision of school districts and attendance areas, and the revision of local laws and regulations which might be necessary in solving such administrative problems. ${ }^{16}$

\footnotetext{
26 Brown v. Board of Education, 349 U.S. 294, 301 (1955).

$\therefore$ It: is interesting to note the varying reactions expressed after the Court handed "down the implementing decision. McKay, "With All Deliberate Speed"-A Study of School Desegregation, supra note 1, at 1000, expresses approval of the delayed implementation of desegregation. "In this succinct phrase ["with all deliberate -speed"] reposes all the urgency of a democracy impatient to be at its task of equality and yet all the dignity and wisdom of the equity jurisdiciton, watchful lest a greater injustice be done in the process of self-defeating haste." For a contrary viewpoint, see Papale, supra note 1, at 308-09: "Unfortunately this [immediate implementation] was not done in the public school cases. . . . It may be too soon to state with any great degree of certainty that this was unwise, but certainly all signs point in that direction." - For discussion of Southern reaction to the implementing decision, see generally Collier, Segregation and Politics, in Wrth Alt Detrberate SpeEd 110, 120-21 (Shoemaker ed. 1957); Leflar, "Law of the Land," in id. at 1.

15 "In fashioning and effectuating the decrees, the courts will be guided by equitable principles. ... Courts of equity may properly take into account the public interest in the elimination of such obstacles in a systematic and effective manner. But it should go without saying that the vitality of these constitutional principles cannot be allowed to yield simply because of disagreement with them.

"While giving weight to these public and private considerations, the courts will require that the defendants make a prompt and reasonable start toward full compliance with our May 17, 1954, ruling. Once such a start has been made, the courts may find that additional time is necessary to carry out the ruling in an effective manner. The burden rests, upon the defendants to establish that such time is necessary to the public interest and is consistent with good faith compliance at the earliest practicable date. To that end, the courts may consider problems related to administration, arising from the physical condition. of the school plant, the school transportation system, personnel, revision of school districts and attendanç areas into. compact: units to achieve a system of determining admission to the public schools on a non-racial basis, and revision. of local laws and regulations which may be necessary, in solving the fore. going problems." Brown v. Board of Education, supra nọte, 14, at 300-01.: (Emphasis added.)

${ }^{30} \mathrm{Ibid}$. Presumably, the object of weighing these considerations is to avoid the lowering of educational standards or interruption in a community's educational system.
} 
From 1955 until the present time, the "deliberate speed" doctrine has had a significant role in the judicial administration of public school desegregation..$^{17}$ However, in the higher education context the courts have specifically rejected its application. ${ }^{18}$ Inasmuch as the admission of Negroes to universities or graduate schools does not entail the administrative problems that desegregation of public schools does, there has been no reason for delay. ${ }^{10}$

In areas involving o:her public facilities in which segregation had previously been practiced, the courts, even though quickly adopting the principle that separate facilities are inherently unequal and thus striking down segregation, have generally not considered

\footnotetext{
${ }^{17}$ Generally, the public school cases subsequent to the second Brown decision discuss "deliberate speed" implementation. For examples of cases upholding the defendants" proposed desegregation plans as qualifying under the "deliberate speed" doctrine, see Hill v. School Bd., 282 F.2d 473 (4th Cir. 1960) (twelve-year desegregation period allowed by "deliberate speed"); Calhoun v. Members of Bd. of Educ., 188 F. Supp. 401 (N.D. Ga. 1959) (same). For examples, on the other hand, of plans that were rejected by the courts because they involved too great delays, see Evans v. Ennis, 281 F.2d 385 (3rd Cir. 1960) (twelve-year period not allowed); Allen v. County School Bd., 249 F.2d 462 (4th Cir.), reversing Davis v. County School Bd., 149 F. Supp. 431 (E.D. Va. 1957) (delay excessive, even though, originally, local conditions required delay); Bush v. Orleans Parish School Bd., 205 F. Supp. 893 (E.D. La. 1962) (board delayed excessively, so immediate compliance with court-formulated plans required).

An interesting observation appears in Leflar, supra note 14, at 13-14: "The resultant judicial pattern has varied with geography. In northern and border areas all deliberate speed' has come to mean 'today' or within time limits firmly set. Further south it means 'soon' or within time limits yet to be fixed. In the Deep South time limits have not been seriously discussed. Local opinion does not change the rule of law which the Supreme Court has found in the Constitution and which lower courts must accept as the high court has stated it, but public opinion does affect the local administrative factors which the district courts have been directed to consider in apply. ing the rule."

${ }^{28}$ The Supreme Court has specified that the decision in the second Brown case has no application to a case involving admission of a Negro to a state professional school. "As this case involves the admission of a Negro to a graduate professional school, there is no reason for delay." Florida ex rel. Hawkins v. Board of Control, 350 U.S. 413, 414 (1956) (per curiam opinion). In Meredith v. Fair, 305 F.2d 343, 352 (5th Cir.), cert. denied, 371 U.S. 828 (1962), the court stated: "As a matter of law, the principle of 'deliberate speed' has no application at the college level...."

The refusal of the courts to desegregate colleges and graduate schools gradually was expected because, first, higher education cases decided prior to the Brown cases ordered immediate desegregation in order to satisfy the "personal and present" rights of the petitioners. E.g., Sweatt v. Painter, 339 U.S. 629 (1950); McLaurin v. Okla. homa State Regents, 339 U.S. 637 (1950). Secondly, the integration of institutions of higher learning does not involve the administrative problems which comprise the criteria necessary for delay in public school desegregation. Universities are not troubled by such problems as redistricting of attendance areas or providing school transportation systems. Furthermore, universities, desegregated or not, are not required to admit more students than they have physical facilities and personnel to handle.

${ }^{10}$ See note 18 supra.
} 
the possibility of delay in the implementation of desegregation. ${ }^{20} \mathrm{~A}$ probable explanation for this is that the courts recognized that the situations involved in those cases also lacked the factors that were present in the Brown and other public school cases and which must be present in order to justify a delayed remedy.

Detroit Housing Comm'n v. Lewis ${ }^{21}$ was relied upon in the instant case as authority for the proposition that the "deliberate speed" doctrine is not limited in application to cases involving public schools. $^{22}$ In that case, defendant Housing Commission, appealing from the decision of the district court requiring desegregation of public housing units, argued that the Commission ought to be allowed reasonable time within which to complete the ordered desegregation. The appellate court interpreted the lower court's judgment to mean that defendants were required immediately to cease maintaining separate lists of eligible Negro and white housing applicants and denying such applicants the right to lease solely because of their race. The resulting change in occupancy might be effected gradually as determined by the normal rate of turn-over among the occupants of the housing units. ${ }^{23}$ Even though the court said that the doctrine of "deliberate speed" was being applied, it is highly improbable that any greater immediacy would have been required if there had been no "reliance" on the doctrine. ${ }^{24}$ This case, then, does

${ }^{20}$ Dawson v. Mayor \& City Council, 220 F.2d 386 (4th Cir.), aff'd per curiam, 350 U.S. 877 (1955). "With this [Brown decision] in mind, it is obvious that racial segregation in recreational activities can no longer be sustained ..." Id. at 387 . In Holmes v. City of Atlanta, 350 U.S. 879, vacating per curiam, 223 F.2d 93 (5th Cir. 1955), the Supreme Court vacated the judgments below npholding segregation in the use of a public golf course and remanded the case to the district court to be decided in conformity with the Dawson case.

For other decisions banning segregation in public facilities, see, e.g., Muir v. Louisville Park Theatrical Ass'n, 347 U.S. 971 (1954), vacating 202 F.2d 275 (6th Cir. 1953) (attendance at performances held in public park); New Orleans City Park Improvement Ass'n v. Detiege, 252 F.2d 122 (5th Cir.), aff'd per curiom, 358 U.S. 54 (1958) (public parks); Department of Conservation \& Dev. v. Tate, 231 F.2d 615 (4th Cir.), cert. denied, 352 U.S. 838 (1956) (same); Dorsey v. State Athletic Comm'n, 168 F. Supp. 149 (E.D. La. 1958), aff'd per curiam, 359 U.S. 538 (1959) (participation of whites and Negroes in athletic contests); Browder v. Gayle, $142 \mathrm{~F}$. Supp. 707 (M.D. Ala.), aff'd per curiam, 352 U.S. 903 (1956) (public transportation). 21226 F2d 180 (6th Cir. 1955).

* 303 F 2d at 869. See also Cummings v. City of Charleston, 288 F.2d 817 (4th Cir. 1961) (dictum) (remedy could be delayed if justifying circumstances appeared). is 226 F.2d at 184.

"The ligher education cases, which talk in terms of "immediacy", are perhaps analogous to this case in that the universities were required immediately, upon the handing down of the judgment, to consider the applications of Negro students on their merits, without regard to race or color, but were not required to admit the qualified 
not negative the conclusion that, prior to Watson, the "deliberate speed" doctrine was restricted to public school cases, presumably because it was in this context that the administrative problems contemplated by the Supreme Court in the second Brown decision were found.

The city of Memphis not only maintains parks, golf courses, and other recreational facilities for its inhabitants to use as they see fit, but also provides an extensive playground system with personnel to organize and direct recreational activities. It is thus readily apparent, that to some extent, the administrative problems contemplated in the Brown case are present here. In considering these problems, the court in Watson ${ }^{25}$ acknowledged the complexity of the recreational system maintained by the city. ${ }^{20}$ After so doing, it found that the city had been making both a good faith effort and considerable progress in bringing about desegregation of its recreation facilities and that immediate desegregation would probably result in the closing of many of these facilities because of the increased personnel that would be required to supervise integrated playgrounds. ${ }^{27}$

The court, however, did not stop with a consideration of the administrative problems involved. In addition to those, the Watson opinion held that other considerations which may be weighed by the courts in determining whether the gradual implementation of already adjudicated personal constitutional rights are the good will and understanding previously obtaining between the races; and the avoidance of confusion and turmoil and the maintenance of law and order in the community during the transition period.28 After considering the foregoing factors in the context of the holding that the application of "deliberate speed" was not limited to school desegregation cases, the court held that gradual implementation was justified in this case. ${ }^{29}$ The court's rationale was that immediate

students until the beginning of the next school term. See Florida ex rel. Hawkins v. Board of Control, 350 U.S. 413 (1956) (per curiam opinion); Meredith v. Fair, 305 F.2d 343 (5th Cir.), cert. denied, 371 U.S. 828 (1962).

$2{ }^{2}$ "[I]t is proper for the Court to consider (1) local conditions and local problems as to facilities, and teacher or supervisory personnel, as well as local problems of maiutaining, during the transition period, maximum recreational facilities for all citizens .... 303 F.2d at 869 (quoting court below).

${ }^{28} I d$. at 865 .

27 Id. at 870 .

${ }^{28} \mathrm{Id}$. at 869 .

${ }^{20} \mathrm{Id}$. at $869-70$. 
desegregation would create not only administrative problems, but also the dangers of confusion and violence, increased antagonism between members of the two races, and the necessity for added police protection. ${ }^{30}$

That the Sixth Circuit overstepped its authority, in adding to the criteria that may be considered by the courts in determining the necessity for delay of desegregation, is indicated by two important points. First, the Supreme Court, in applying the "deliberate speed" doctrine in the Brown case, specifically limited the criteria to be considered by the courts to administrative problems. ${ }^{31}$ The factors added by the court in the instant case are clearly not of an administrative nature, but rather are policy matters, the consideration of which would allow broad discretion on the part of the courts. Second, the last factor authorized for the court's consideration in the Watson case is the avoidance of confusion and turmoil and the maintenance of order. It has long been the law that a person's constitutional rights cannot be sacrificed or their recognition delayed for this reason. ${ }^{32}$

The effect of the decision in Watson $v$. City of Memphis, then, could be more profound than is indicated by its extension of the doctrine of "deliberate speed" to other than public school cases. The decision substantially increases the breadth of criteria which a

${ }^{30}$ Id. at 868,870 . Judge McAllister emphasized the point that the plaintiffs did not question any of the city's evidence sustaining these findings, but rather regarded it as irrelevant. Id. at 868.

82349 U.S. at $300 \cdot 01$.

32 Any consideration of possible violence or disruption of relations was rejected in Cooper v. Aaron, 358 U.S. 1 (1958). The Court, in ruling on the desegregation of the Little Rock schools, held: "[L]aw and order are not here to be preserved by depriving the Negro children of their constitutional rights." Id. at 16.

In Buchanan v. Warley, 245 U.S. 60, 81 (1917), holding discriminatory municipal zoning invalid, the Court stated: " $1 \mathrm{t}$ is urged that this proposed segregation will promote public peace by preventing race conflicts. Desirable as this is, and important as is the preservation of the public peace, this aim cannot be accomplished by laws or ordinances which deny rights created or protected by the Federal Constitution."

When people are led to act illegally because an individual exercises his legal right; it is proper procedure to protect the legal right, if necessary by punishing those who use illegal means to oppose it. See Sellers v. Johnson, 163 F.2d 877, 883 (8th Cir. 1947), where the court held that the police were not entitled, in order to avoid public conflict, to prevent the Jehovah's Witnesses from holding a meeting. The police should have acted, instead, against the mob which threatened violence.

See also Terminiello v. Chicago, 337 U.S. 1 (1949); Cantwell v. Connecticut, 310 U.S. 296 (1940); Schneider v. State, 308 U.S. 147 (1939); Hague v. CIO, 307 U.S. 496 (1939); Stromberg v. California, 283 U.S. 359 (1931). But cf. Feiner v. New York, 340 U.S. 315 (1951). 
court may consider in determining whether "deliberate speed" may be employed in the implementation of the appropriate remedy for an adjudicated right. Relying on the additional criteria, a court could effect delays in desegregation for reasons not previously allowed. This would, in effect, allow the courts almost unlimited latitude in deciding whether gradual desegregation is warranted in a particular case.

The Supreme Court, in the public school cases, has answered the question initially asked by holding that the vindication of already adjudicated personal rights may be delayed for the furtherance of the public interest, not when the public disagrees with the action or when the delay would help to maintain order, but rather when the presence of administrative problems makes the implementation of immediate desegregation impracticable. If, then, the Brown factors were present in a case involving desegregation of a public facility other than public schools, as in the instant case, it would appear to be unreasonable to deny the applicability of "deliberate speed" simply because of the type of public facility involved. Therefore, strict adherence to the criteria established by the Supreme Court in Brown v. Board of Education, rather than consideration of the public facility involved, should be the determinant as to whether desegregation may be implemented gradually. On this basis only, because of the administrative problems involved therein, the result in the instant case may be a proper one. However, because of the improper criteria considered in its determination, Watson $v$. City of Memphis should be vacated and remanded for decision as to whether the administrative problems incident to the desegregation of these public recreational facilities warrant the application of the doctrine of "deliberate speed." 